Check for updates

The BMJ

Cite this as: $B M / 2022 ; 376: 0383$ http://dx.doi.org/10.1136/bmj.0383 Published: 15 February 2022

\title{
Covid-19: Show us evidence for lifting restrictions, doctors tell Johnson
}

\section{Adele Waters}

Doctors and scientists have warned the prime minister that SARS-CoV-2, and not politics, should dictate the pace at which the UK lifts measures to contain the pandemic.

They expressed their concern after Boris Johnson's announcement during prime minister's questions in parliament on 9 February that he intended to end all remaining restrictions four weeks early if "encouraging trends" continued. The move would see the restrictions, including the current legal requirement to self-isolate after a positive test result, ending as early as 24 February.

The BMA responded by calling for the government to provide evidence for its position. Penelope Toff, chair of the association's public health medicine committee, said, "With case rates still incredibly high and hundreds of deaths each day, the suggestion that self-isolation may be removed this month runs contrary to good public health practice. We must question on what scientific basis this decision is being made, and the government needs to show the evidence behind its proposals."

In the days after the announcement it became clear that Johnson had not acted on the advice of the Scientific and Advisory Group for Emergencies (SAGE). Downing Street later confirmed that the decision had instead been prompted by a recent fall in rates of hospital admission.

But many scientists have said that declining admission rates could not be interpreted as a sign that the virus no longer presented a danger.

Peter Openshaw, professor of experimental medicine at Imperial College London, who advises the government on covid through the New and Emerging Respiratory Virus Threats Advisory Group (Nervtag), said that the plan did not seem very cautious in terms of its overall health impact. "It would be wholly wrong to call the pandemic over," he told the BBC. "I'm still very concerned that the number of cases remains very high-we are still seeing 300 deaths a day."

Iain Buchan, chair of public health and clinical informatics at the University of Liverpool and a SAGE member, emphasised the need for continued caution, redeploying covid risk mitigations quickly and flexibly, according to intelligence. "It is wise to ramp measures down gradually and up rapidly, guided by data on the prevailing biology, behaviours, and environments," he told The BMJ.

Simon Clarke, associate professor in cellular microbiology at the University of Reading, said that lifting the self-isolation requirement would prove to be either "very brave or very stupid."

He said, "Omicron may be on the wane in Europe, but other parts of the world are still in the full flush of a surge in infections ... As we have seen before, the virus is in the best possible position to mutate again, and there is absolutely no certainty that any new variant would be less dangerous."

Many experts singled out their concern for vulnerable people if restrictions were lifted too early. Marian Knight, professor of maternal and child population health at the University of Oxford and an occasional adviser to SAGE, said her main worry was indirect consequences. "We're still seeing large numbers of pregnant women admitted to hospital with covid," she told The BMJ. "But we also know that, more than anything in pregnancy, attending for your antenatal visits is crucial, so anything that makes women less confident in attending their routine antenatal and postnatal visits is of concern to me.”

Lawrence Young, a virologist and professor of molecular oncology at the University of Warwick, said it was important to protect clinically vulnerable people. "We are likely to see people being reinfected. The pandemic isn't over, and if we've learnt anything over the last two years it's that the impact and future of covid-19 remains unpredictable."

Johnson announced last month that he did not expect to renew covid regulations that are due to expire on 24 March. ${ }^{1}$ The government is now expected to publish its cross department strategy on living with covid on 21 February. $^{2}$

A Downing Street spokesperson said that any plan to lift covid restrictions would be subject to independent advice.

Gov.UK PM statement to the House of Commons on Covid-1919 Jan 2022 https://www.gov.uk/government/speeches/pm-statement-to-the-houseof-commons-on-covid-19-19-january-2022.

2 Waters A. Covid-19: Long term plan on living with pandemic to come in spring, says Javid. BMJ 2022;376:0235. doi: 10.1136/bmj.o235 pmid: 35086809

This article is made freely available for personal use in accordance with BMJ's website terms and conditions for the duration of the covid-19 pandemic or until otherwise determined by BMJ. You may download and print the article for any lawful, non-commercial purpose (including text and data mining) provided that all copyright notices and trade marks are retained. 